Aksaray University
Journal of Science and Engineering
e-ISSN: 2587-1277
http://dergipark.gov.tr/asujse
http://asujse.aksaray.edu.tr

Research Article

\title{
TrackARTI: Mobile Health Tracking System for Pediatric Patients with Acute Respiratory Tract Infection
}

\author{
Duygu Celik Ertugrul ${ }^{1, *}$, Metin Zontul $^{2}$, Yiltan Bitirim¹, Gökhan Taymaz ${ }^{2}$ \\ ${ }^{1}$ Computer Engineering Department, Engineering Faculty, Eastern Mediterranean University, Famagusta, North \\ Cyprus, via Mersin-10, Turkey \\ ${ }^{2}$ Software Engineering Department, Engineering Faculty, Istanbul Aydin University, Istanbul, Turkey
}

-Received Date: 02 Mar $2018 \quad$-Revised Date: 19 Apr $2018 \quad$ •Accepted Date: 17 Jun $2018 \quad$ Published Online: 25 June 2018

\begin{abstract}
This study introduces the Remote Medical Tracking Mobile System (TrackARTI) which guides parents or health expert users in the treatment of Acute Respiratory Tract Infections (ASYE) diseases for children aged 0-6 years. The main purpose of this system is to gather actual data belonging to the medical cases of ASYE period in various environments instantly, to display them when requested, to store them in structural form in order to understand by machines, to deduce the data through its retrieval mechanism and to make personalized medical suggestions or to present relevant new data inferred. The main user group of the system is pediatric specialists and parents. The main stakeholders of this system are parents, child patients, pediatric specialists and health personnel. The proposed TrackARTI system is an example of intelligent M-Health systems. The system has two basic outputs: TrackARTI Artificial Intelligence based Inferencing Mechanism and TrackARTI Mobile Application. In addition, the Artificial Intelligence based Inferencing Mechanism of the system involves two main activities in itself; 1) Medical Image Processing based Inferencing and 2) Semantic Web Based Inferencing of new medical data and suggestions through its Inference Rules.
\end{abstract}

\section{Keywords}

Smart Mobile Systems, Acute Respiratory Infection Monitoring System, Semantic Web, Ontology Knowledge Base, e-Health, m-Health, Inferencing

\footnotetext{
"Corresponding Author: Duygu Celik Ertugrul, duygu.celik@emu.edu.tr
} 


Aksaray University
Journal of Science and Engineering
e-ISSN: 2587-1277
http://dergipark.gov.tr/asujse
http://asujse.aksaray.edu.tr

Research Article

\title{
TrackARTI: Akut Solunum Yolu Enfeksiyonu Geçiren Çocuk Hastalar için Mobil Sağlık Takip Sistemi
}

\author{
Duygu Çelik Ertuğrul ${ }^{1, *}$, Metin Zontul², Y1ltan Bitirim ${ }^{1}$ Gökhan Taymaz ${ }^{2}$ \\ ${ }^{1}$ Bilgisayar Mühendisliği Bölümü, Mühendislik Fakültesi, Doğu Akdeniz Üniversitesi, Gazimağusa, K.K.T.C, \\ Mersin 10, Türkiye \\ ${ }^{2}$ Yazılım Mühendisliği Bölümü, Mühendislik Fakültesi, İstanbul Aydın Üniversitesi, İstanbul, Türkiye \\ -Gönderi Tarihi: 02 Mar 2018 •Düzeltme Tarihi: 19 Nis $2018 \quad$-Kabul Tarihi: 17 Haz 2018 -Çevrimiçi Yayın Tarih:25 Haz 2018
}

\section{Özet}

Bu çalışma, 0-6 yaş arası çocuklardaki Akut Solunum Yolu Enfeksiyonları (ASYE) hastalıklarının tedavisinde ebeveynlere veya sağlık uzmanlarına rehberlik eden bir Uzaktan Tıbbi Takip Sistemi'ni (TrackARTI) incelmektedir. Bu sistemin temel amacı, ASYE dönemlerindeki medikal vakalara ait gerçek verileri çeşitli ortamlarda anlık olarak toplamak, istenildiğinde görüntülemek, makinelerin anlayacağı şekilde yapısal formda saklamak, sistemin kendi çıkarım mekanizması sayesinde yorumlayıp kişiye özgü medikal önermeler yapmak veya çıkarsınmış ilgili yeni verileri sunmaktır. Sistemin temel kullanıcı grubu pediatri uzmanları ve ailelerdir. Bu sistemin ilk paydaşları ebeveynler, çocuk hastalar, pediatri uzmanları ve ilgili sağlık personelidir. Önerilen TrackARTI sistemi akıllı M-Sağlık sistemlerine bir örnek teşkil etmektedir. Sistemin, TrackARTI Yapay Zekâ Çıkarım Mekanizması ve TrackARTI Mobil Uygulaması olmak üzere iki temel çıktısı bulunmaktadır. Ayrıca, Yapay Zekâ Çıkarım Mekanizması kendi içinde iki temel çalışmayı içermektedir; 1) Medikal Görüntü İşleme tabanlı çıkarımlar ve 2) Anlamsal Veb Tabanlı Çıkarım Kuralları yoluyla yeni veriler ve önermelerin çıkarsaması.

\section{Anahtar Kelimeler}

Akıllı Mobil Sistemler, Akut Solunum Yolu Enfeksiyon İzleme Sistemi, Anlamsal Veb, Ontoloji Bilgi Tabanı, e-Sağlık, m-Sağlık, Çıkarım

\footnotetext{
*Sorumlu Yazar: Duygu Çelik Ertuğrul, duygu.celik@emu.edu.tr
} 


\section{GÍRİş}

M-Sağlık son yıllarda üstel bir büyüme yaşayan e-Sağlık uygulama alanlarından en popüler olanıdır. Hastalıkların güvenilir bir şekilde uzaktan tanı, teşhis ve takip edilmesinde önemli katkı sağlayan bu teknoloji, kullanıcılara kaliteli sağlık hizmeti sağlamak ve sağlık sektöründe verimi arttırmak için büyük öneme sahiptir. M-Sağlık sistemleri ile çocuk hastaların, hastalık dönemleri boyunca, gerekli olan gözlem ve takibin dijital ortamdan yapılması ve anlık tıbbi verilerin toplamasını amaç edinmiş çeşitli çalışmalar ve hizmetler ortaya sürülmüş ve çözümler önerilmiştir [1-9]. Bu tür çözümler sağlık sektöründe artmaya başladıkça, popüler olma yoluna girmiş, böylece zamanla ebeveynlerin ilgi odağı olmuştur. Çocuklarının hastalık dönemlerinde tedbiri sağlamak ve uygun önleyici tedavi adımlarını atmak isteyen ebeveynler, uzaktan takip sistemlerine kapılarını açmaya başlamıştır.

Ülkemizde ve dünyada akıllı telefon teknolojisine olan yüksek talebe bakıldığında, sağlık sektöründe mobil uygulamaların geliştirilmesine yönelik artış gösteren bir hareketin olması şaşırtıcı değildir. Baysari, MT [10] çalışmasında ve Research-2-Rehberlik [11] araştırma raporunda, tahmini olarak 100,000'den fazla M-Sağlık uygulamasının dijital marketlerde yer aldığından bahsetmiştir. Bu sağlık uygulamalarının birçoğu kronik hastalıklar (\%31), sağlık ve fitnes (\%28) ve sağlık hizmeti (\%14) için tasarlanmıştır. Ayrıca, marketlerdeki mevcut mSağlık uygulamaları çeşitli kitlelere hitap edebilmektedir. Örneğin; tıbbi materyalleri arama, hastaların sağlik problemlerini izleyebilme ve görüntüleme, yakındaki doktor kliniklerini ve eczanelerin gösterilmesi ve çeşitli tıbbi kayıtların toplanması (semptomlar, zihinsel durum, gıda takviyeleri, hastalara ilaç alımını hatırlatmak için hatırlatıcılar ve talimatlar vb.) için uygulamalar geliştirilmiştir.

Çocuklarda enfeksiyonlara açı en duyarlı sistem, Akut Solunum Yolu Enfeksiyonu (ASYE) olarak bilinen solunum yolu hastalıklarıdır [12]. Bu nedenle, soğuk algınlığ iltihabı, otitis vb. gibi solunum yolu enfeksiyonları çocukluk döneminin en yaygın bulaşıcı hastalıklarıdır [12, 13]. 0-6 yaş grubundaki çocuk hastaların, yaşam kalitesini üst düzeye çıkarmak, gerektiğinde kayıtlı doktoru tarafından uzaktan her an teşhis ve takibini yapmak ve çocukların hastalık dönemlerinde yaşanan ebeveyn kaygılarını azaltmak mümkündür. $\mathrm{Bu}$ nedenle, akıllı m-Sağlık sistemlerinin gelişmesiyle, solunum yolu enfeksiyonuna yakalanan çocuk hastaların hastanelerden uzak ortamlarda teşhis edilmesi ve izlenmesi mümkün olup, toplanan anlık tıbbi veriler sistemdeki kayıtlı doktorlar tarafından anlık görüntülenebilmektedir. Klasik m-Sağlık sistemlerinden yapay zekâ tabanlı m-Sağlık sistemlerine geçiş gereksinimi artmıştır. Yapay zekâ tabanlı m-Sağlık sistemleri, medikal cihazlardan veri toplanmasını, 
verilerin makinelerce anlaşılabilir yapısal bir biçime dönüştürülmesini, makine öğrenmesi ya da veri madenciliği gibi teknikler ile toplanan verilerin analizini ve yorumlanmasını içermektedir. Yapay zekâ tabanlı m-Sağlık sistemler ile uzaktan çocuk hastaların izlenmesi sırasında elde edilen tıbbi veriler üzerinden yeni veriler çıkarsaması mümkündür. Elde edilen yeni veriler, akıllı cihazlar aracılığıyla hastanın zamanla biriken mevcut tıbbi kayıtlarının makinelerce yorumlanmasından elde edilen anlamlı verilerdir. Örneğin; her vaka için bir hastalığın yaşanma sıklığı, belli zaman aralığında (günlük, haftalık, aylık, yıllık vb.) gözlemlenen tüm hastalık türleri ve sıklığı, gözlemlenen her hastalık türü için sıkça görülen semptomlar vb. veriler ile anlamsal bilgiler çıkarsanabilir. TrackARTI gibi sistemler ile, aileler veya yetkili sağlık personeller tarafından çocuk hastaların hastalık dönemlerinde sitemin mobil uygulaması üzerinden istenildiğinde tıbbi verilerin kolaylıkla toplanıp depolanması ve bu verilerden yukarıda bahsi geçen türde anlamlı verilerin çıkarsaması mümkün olmaktadır. Böylece, hastaya, doktoruna ve ebeveyne sağladığı faydaların yanı sıra; zamanla, bir toplulukta/toplumdaki 0-6 yaş grubu hastalarda gözlemlenen hastalık yaygınlığı, insidansı, saldırı hızı ve epizot hızı vb. bilgilerin çıkarımı sayesinde toplumun sağlık demografisi hakkında önemli bilgiler de elde edilebilecektir.

$\mathrm{Bu}$ makalede akut solunum yolu enfeksiyonu için 0-6 yaş grubu çocuklara yönelik Uzaktan Medikal Takip Mobil Sistemi (TrackARTI) önerilmektedir. Sistemin; bir adet TrackARTI Yapay Zekâ Çıkarım Mekanizması ve bir adet TrackARTI Mobil Uygulaması olmak üzere, iki temel çıktısı bulunmaktadır. Yapay Zekâ Çıkarım Mekanizması kendi içinde iki temel çalışmayı içermektedir; 1) Medikal Görüntü İşleme teknikleri ile çıkarımlar (elde edilen medikal görüntü verileri üzerinden) ve 2) Anlamsal Veb Tabanlı Çıkarım Kuralları ile yeni medikal verilerin ve tedavi destek önermelerinin çıkarsaması. Yapay Zekâ Çıkarım Mekanizması ile ailelere ve ilgili sağlık ekibine 0-6 yaş grubundaki çocukların hastalık dönemlerinde yardımcı olacak bazı destekleyici öneriler sunulabilmektedir. Zamana bağlı olarak hastayı tanımlayıcı genel demografik yeni verilerin oluşturulmasıyla, sorumlu sağlık personelinin, o hasta hakkında karar vermesinde destekleyici olacaktır. Bu makale, TrackARTI sisteminin, yalnızca TrackARTI App’ı ve Anlamsal Veb Kuralı Tabanlı Çıkarım mekanizması üzerine yoğunlaşmıştır. TrackARTI sisteminin görüntü işleme algoritmaları ile çıkarım mekanizması, gelecek makale çalışmalarımızda tartışılacaktır. İlaveten, sistemin bir toplulukta/toplumdaki 0-6 yaş grubu hastalarda gözlemlenen hastalık yaygınlığı, insidansı, saldırı hızı ve epizot hızı vb. bilgilerin çıkarımı, ancak zamanla sistemdeki hasta sayısı arttıkça oluşacaktır. $\mathrm{Bu}$ nedenle, bu konular gelecek makalelerimizde işlenecektir. TrackARTI'nın Anlamsal Veb Tabanlı Çıkarım mekanizması, TrackARTI App'ını kullanan ailelere veya 
sorumlu sağlık personeline, sistemin yapay zekâ kuralları çerçevesinde, çocuk hastaya uygun tedavi destek süreç önermeleri üretmektedir.

$\mathrm{Bu}$ yazının geri kalan kısmı aşağıdaki gibi düzenlenmiştir: Bölüm 2 benzer araştırma çalışmalarını ve akıllı cihazlara takılabilen bazı yenilikçi medikal mobil cihaz ve aparatları tartışmaktadır. Bölüm 3, çocuk hastalardan alınan tıbbi verileri toplamak için, sistemin veri toplama mekanizmasını sunmaktadır. Bölüm 3, aynı zamanda benzer m-Sağlık projelerini ve TrackARTI mobil sistemini katkıları bakımından kıyaslamaktadır. Bölüm 4, TrackARTI sisteminin ontoloji bilgi tabanı ve çıkarım kurallarının yapısını açıklarken, Bölüm 5 sistemin çıkarım motorunun geliştirilmesi hakkında bilgi vermektedir. Bölüm 7, sonuçlara ayrılmıştır.

\section{LITERATÜR TARAMASI}

Akut Solunum Yolu Enfeksiyonu (ASYE), çocukluk çağında, morbidite ve mortalitenin önemli bir nedenidir [12]. 0-6 yaş grubu küçük çocuklarda, hastanelere yapılan başvuruların yarısı ASYE'ye bağlıdır. Okul öncesi dönemdeki her çocuk yılda 5-8 kez bir ASYE'ye bağlı bir hastalığa yakalanabilmektedir. ASYE, altı aydan büyük çocuklarda, anneden geçen antikorların kaybolması nedeniyle çok yaygın olarak toplumda görülmektedir [12]. Sık görülen ASYE'den biri Akut Otitis Media (AOM)'dır. Üç yaşına kadar çocukların yaklaşık \%85'i en az bir kere AOM hastalığına yakalanır ve bunların \%50'sinde iki veya daha fazla tekrarlanır [13]. Bu hastalık, en sık 6-36 ay arasındaki çocuklarda görülmektedir. Bir yaşından önce Otitis Media hastalığına yakalanan çocuklarda tekrarlama riski yüksektir [12,13].

Çocukluk döneminde görülen diğer en sık rastlanan hastalık ise Akut Farenjit’tir. Akut tonsillit ve Farengotonsilizm de dahil olmak üzere, farenks içeren akut enfeksiyonlar genellikle Akut Farenjit olarak adlandırılır. En sık 4-7 yaş arasında görülür [13]. Farenjit, burun akıntısı, öksürük ve ses kısıklığı gibi semptomlara sahiptir ve genellikle viral olarak düşünülmektedir $[12,13]$. Vücut sıcaklığı genellikle çok yüksektir ve çocuğun genel durumu aşırı bozulmaz. Bununla birlikte, bakteriyel farenjitli çocuğun genel durumu daha ciddi bozulabilmekte ve ateşi $40{ }^{\circ} \mathrm{C}^{\prime}$ ye yükselebilmektedir. Belirtiler, baş ağrısı, karın ağrısı ve kusmayı içerebileceği gibi, bu semptomlar değişik seviyelerde olabilir (örneğin; Hafif, Orta ve Şiddetli). Vücuttaki streptokokal döküntü de görülebilmektedir. Bunlarla birlikte, bademcikte eksudatlar gözlemlenebilir ve izlenebilir [12, 13].

ASYE kökenli bu tür hastalıkların yaşandığı dönemlerde, hastaları daha iyi teşhis ve gözlem imkânı sağlayacak ve bu tür hastalıkların semptomlarını ve anlık seviyelerini dijital ortamda sürekli olarak toplayacak, yönetebilecek ve gerekli çıkarımları yapabilecek, güçlü bir bilgi 
bankası yönetimine sahip akıllı m-Sağlık sistemlerine gereksinim oldukça fazladır [12,13]. Son zamanlarda, mobil marketlerde benzer tür sistemlere rastlamak mümkündür. Genellikle, bu ürünler araştırma projeleri olarak karşımıza çıkmaktadır. Bunlar mobil cihazlara ek medikal aparatlar takılmasıyla, hasta verilerinin toplanması, yapısal hale getirilmesi ve yönetimini amaçlamaktadır [14-27].

CellScope (eski adı ile Remotoscope, bkz. Şekil 1) [14, 15], standart bir akıllı telefonu dijital otoskop cihazına çeviren, basit bir klips sistemi olan ve kulak enfeksiyonlarının uzaktan teşhis edilebilmesi için hekimlere kolaylık sağlayan mobil entegre bir otoskop projesidir.

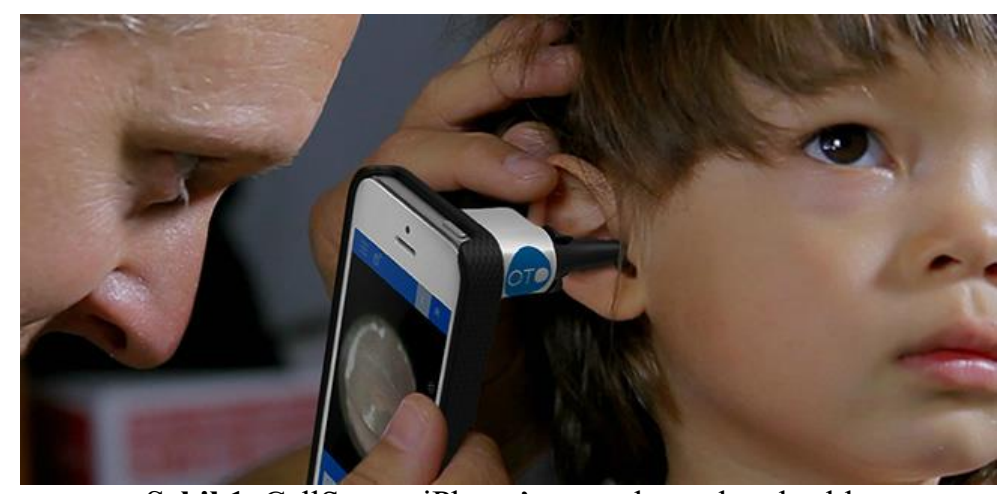

Şekil 1. CellScope, iPhone'ye uyarlı otoskop başlık.

Amaç, doktorların çocuklarda kulak enfeksiyonlarını uzaktan teşhisini sağlamaktır. Ebeveynler, akıllı telefonlarının kamerasına tutturdukları CellScope otoskop başlık aparatı yardımıyla, çocuklarının iç kulağından bir görüntü alabilmekte ve anlık olarak tanı koyabilecek kayitlı doktoru ile paylaşabilmektedir. Kablosuz iletişimi, her yerde yüksek kaliteli görüntüler almayı ve akıllı telefonları bir otoskop olarak kullanmayı sağladığından her yerden kulak enfeksiyonlarının teşhisi ve takibi için bir çözüm olarak sunulmuştur [15].

Diğer bir aparat ise, akıllı telefonlar aracılığıyla, herhangi bir yüzeyden daha net görüntüler elde etmeyi sağlayan, ön uç-ekleme-kamera lensidir [16] (Şekil 2). Böylece, iç kulak haricinde, diş kulak yüzeyinde de gözlemlenebilen, irin ve iltihabın, rengi ve yoğunluğu hakkında net görüntü almayı sağlar.
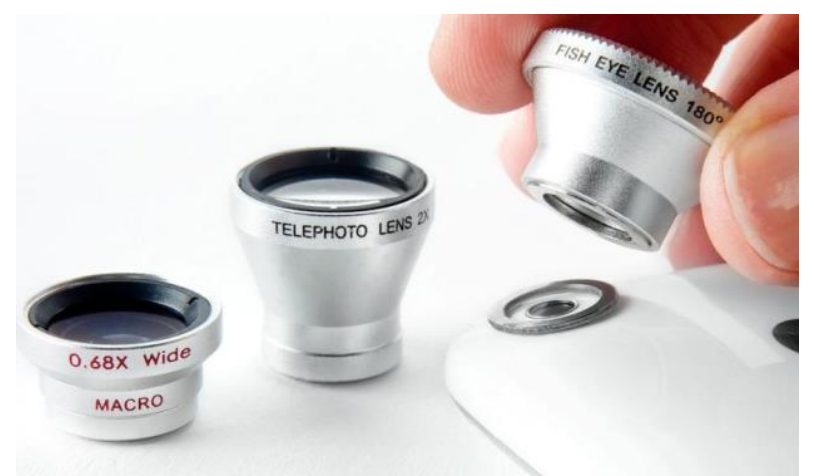

Şekil 2. Manyetik mobil cihaz lens aparatı. 
Diğer bir çalışma, akıllı telefonlar için düşük maliyetli, dijital stetoskop araştırma ve geliştirme projesi olan StethoMic [17]' dir. Bu araştırma, pnömoni, astım ve diğer solunum yolu hastalıklarını doğru bir şekilde teşhis etmek maksadıyla, makine öğrenimi tekniklerini kullanır. StethoMic gibi benzer diğer deneysel dijital stetoskop projeleri [18-26] literatürde ve dijital marketlerde mevcut olup geliştirilmeye devam edilmektedirler.

VitaDock [27] (eski adıyla ThermoDock) kızılötesi ateş termometresi olup, iPhone, iPod touch veya iPad akıllı cihazların veri portuna takıldığında mobil uygulaması sayesinde kişinin alnından saniyeler içinde vücut sıcaklığını ölçer.

M-Sağlık alanında teknolojik çözümlerin artmasıyla birlikte sağlık hizmet süreçleri daha kolay hale gelmiş ve hastaların refah seviyeleri artmıştır. Özellikle, biriken hasta verilerinin tanı ve tedavi faaliyetlerinde yapay zeka yaklaşımlarıyla değerlendirilmesi, sağlık sektöründe büyük katkı sağlamaktadır.

Anlamsal Veb (AV), bilinen İngilizce adıyla Semantic Web (SW) [28], mevcut Veb yapısının bir uzantısı olarak ortaya atılmış ve bilginin düzgün tanımlanmış bir anlama sahip olduğu ve insanlar ile bilgisayarların beraber çalışabildikleri yeni bir Veb teknolojisidir. Diğer bir deyişle, Veb içeriklerinin sadece doğal dillerde değil, aynı zamanda ilgili yazılımlar tarafından anlaşılabilir, yorumlanabilir ve kullanılabilir bir biçimde ifade edilerek, bu yazılımların veriyi anlamsal tabanda araması, paylaşması ve yeni bilgilerin çıkarsaması sağlanır. AV teknolojisinin en büyük katkısı Ontoloji [29] bilgi tabanıdır. Ontoloji, belirli bir alanın kavramsallaştırılmasına ilişkin bir spesifikasyondur. Bir alana ait kavramların öğeleri ve ilişkilerini açıklamaya yarayan yapısal düzeni olan bir sözcük kümesidir. Son zamanlarda, Kaynak Tanımlama Çerçevesi (Resource Description Framework - RDF) [30] ve Veb Ontoloji Dili (Ontology Web Language - OWL) [31] gibi birçok AV dilleri önerilmiş ve World Wide Web (W3C) konsorsiyumu tarafindan standartlaştırılmıştır. W3C göre; OWL, bir bilgi temsil dilleri ailesi olup, ontolojiler üzerinde akıl yürütme / çıkarım yapmayı sağlar. OWL'in en son sürümü OWL 2.0'dır [32]. OWL, bir alana ait, kavramları ve kavramlara ait özellikleri, kısıtları vb. yapıları ontolojik formda ifade etmeyi sağlar. Böylece ontolojiler sayesinde, dağıtık bilgi sistemlerindeki heterojen bilginin anlamsal bağlantısı ve eşlemesi mümkün olabilmektedir. İlaveten, AV teknolojisi günümüzde birçok farklı alanlara ve sistemlere uyarlanabildiği gibi kişisel sağlık sistemlerine ve e-Sağlık araçlarına entegre edilebilir bir teknolojidir. OWL dili kullanılarak geliştirilen medikal tabanlı ontolojiler sayesinde, heterojen yapıdaki kişisel sağlık verilerinden yeni verilerin çıkarsaması mümkündür. Örneğin; bir medikal ontoloji bilgi tabanında, çocukluk çağında sıklıkla tekrarlayan ASYE kökenli hastalıklar, hastalıkların 
özellikleri, gözlemlenen semptomları vb. bilgiler (kavramlar, özellikler, ilişkiler, öğeler, kısıtlamalar vb. yapılar halinde) makinelerin anlayacağı biçimde yapısal hale getirilerek, hastalardan elde edilen anlık veriler makinelerce yorumlanabilir. Dolayısıyla, bu tür anlam bilgi tabanları üzerinde çalışan yazılımların geliştirilmesi ile, olası semptomların, ilgili medikal verilerin ve tedavi destek süreçleri vb. bilgilerin çıkarsaması mümkündür.

\section{MEDİKAL VERILERIN TOPLANMASI}

Bu bölümde, sistemin TrackARTI Mobil Uygulaması sayesinde, kayıtlı bir uzmanın muayene esnasında veya bir ebeveynin ev ortamında, bir çocuk hastadan anlık medikal verileri nasıl toplandığ 1 anlatılmıştır. Ayrıca, toplanan bu verileri, sistemin veri tabanına nasıl aktarıldığından ve çıkarım istendiğinde, bu verilerin ontoloji bilgi tabanında nasıl kullanıldığından bahsedilmiştir.

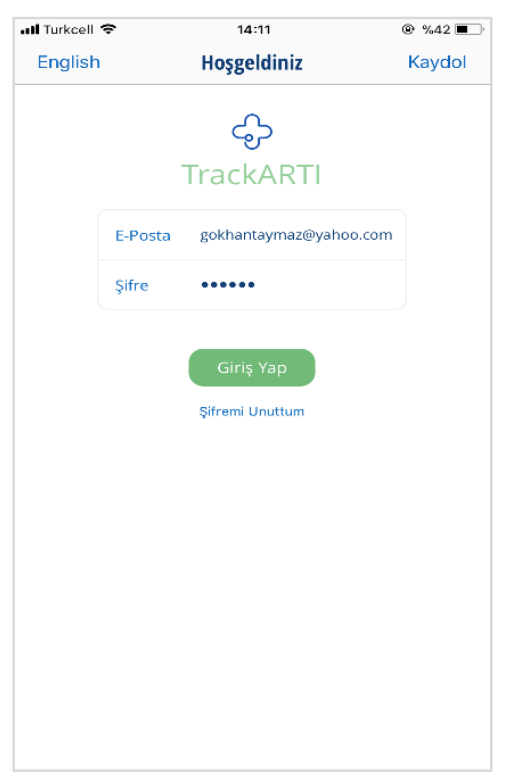

(a) TrackARTI giriş işlemi

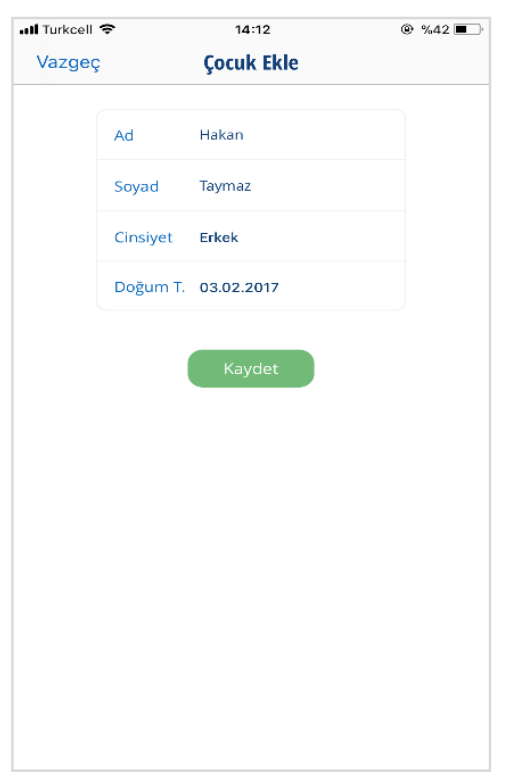

(b) Çocuk kayıt işlemi

Şekil 3. TrackARTI Mobile App ile kullanıcı girişi/kayıt/ayarları ve çocuk ekleme işlemleri.

Öncelikle, bir çocuk doktorunun veya bir ebeveyn kullanıcının, bir çocuk hastanın ASYE dönemi süresince anlık bazı önemli tıbbi verilerini toplamak için TrackARTI Mobile App’1 kullanması gerekmektedir. Eğer kullanıcının hesabı yok ise yeni bir hesap kolayca oluşturabilmektedir. Ebeveyn/doktor yeni bir kullanıcı hesabı oluştururken, kendi isim, soy isim, e-posta, telefon ve şifre bilgisini girerek hesap oluşturma işlemini tamamlamaktadır. Hesabı var ise, kullanıcı girişi bölümünden direk giriş yapabilmektedir (Şekil 3.a). TrackARTI mobil uygulaması, kullanıcının cihaz diline göre Türkçe veya İngilizce olarak açılabilmektedir. İstenildiği takdirde, giriş ekranından ve hesap işlemleri bölümünden uygulama dili değiştirilebilmektedir. Sisteme girildiğinde, çocuklar ekranı eğer boş ise, kullanıcı yeni çocuk 
ekleme sayfasına yönlendirilmektedir (Şekil 3.b). Bu bölümde, çocuğa ait olan isim, soy isim, cinsiyet ve doğum tarihi bilgisi girilerek yeni bir çocuk ekleme işlemi tamamlanabilmektedir. Kullanıcı, çocuklar ekranında seçim yaptıktan sonra, muayeneler ekranına yönlendirilmektedir. Çocuğa ait tıbbi verileri girebilmek için, muayeneler ekranında yeni bir ön-muayene kartı açabilmektedir. Kullanıcı, çocuk hastadan o an gözlemlediği aşağıda bahsedilen bazı tıbbi verileri açmış olduğu ön-muayene kartı üzerinde doldurmasıyla işleme başlar. Kısıtlı sayfa sayısı nedeniyle, bazı ekranlara makalede yer verilememiştir.

Şekil 4'te bir ön-muayene kartı gösterilmiştir. Örnek vaka "Hakan Taymaz" için açılan 03.02.2018 20:41 tarih ve zamanlı ön-muayene kartı üzerinde medikal veriler kullanıc1 tarafından toplanmıştır. Ekranda alt kısımda ki "Gönder" tıklanarak veriler sistemin veri tabanına gönderilebilmektedir.

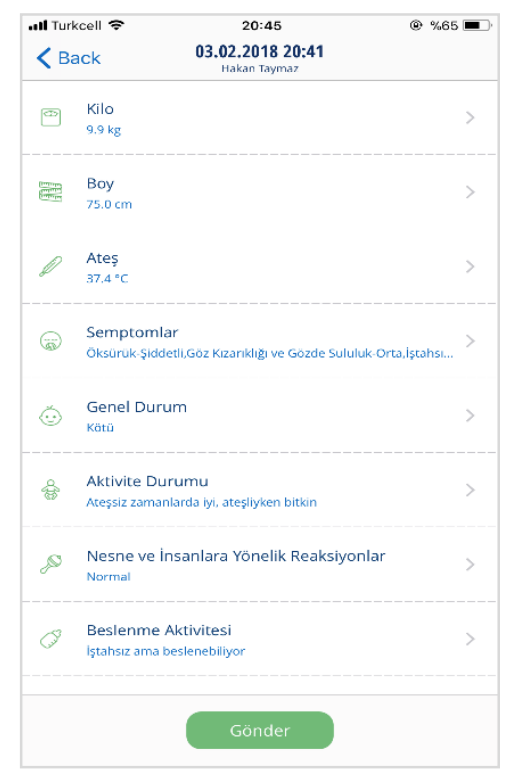

(a) Ön-muayene kartının başlangıcı

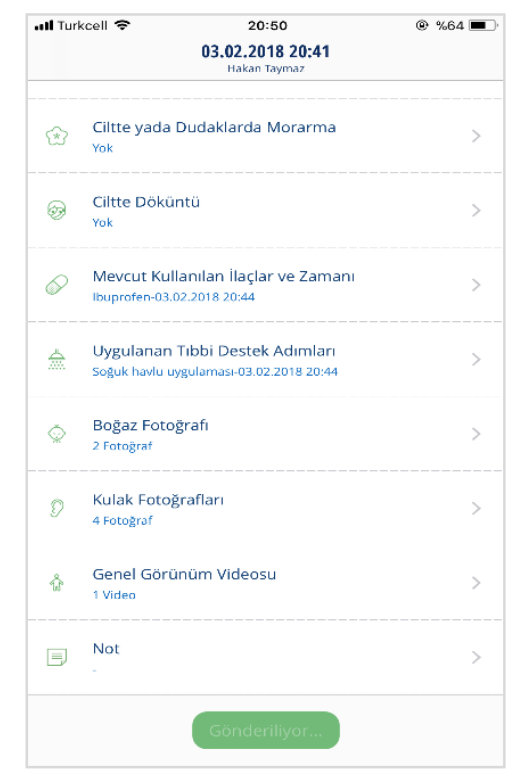

(b) Ön-muayene kartının devamı

Şekil 4. TrackARTI Mobile App'ı ile doldurulmuş bir ön-muayene kartının "gönderme" işlemi.

Sistemin yapay zekâ çıkarım mekanizması, bu ön-muayene kartları üzerinden kişiye özgü toplanan, tüm resim ve metin tabanlı medikal verilerin işlenmesiyle çalışmaktadır. Çocuk hastalıkları uzmanları ile yapılan çalışmalara dayanarak, TrackARTI mobil uygulamasındaki bir ön-muayene kartı (Şekil 4) üzerinde hastalardan aşağıdaki anlık verilerin toplanması önemli görülmüştür:

1- Güncel Kilo (kg): Kilo bilgisi ekranı, Şekil 5.a'da yer alan çocuğun tarih seçimi ile birlikte kilo bilgisinin girildiği ekrandır. Kilo bilgisi seçeneği çocuğun cinsiyet ve yaş bilgisine göre ortalama bir aralıkta açılarak kullanıcıya seçim için kolaylık sağlamaktadır. Kilo bilgisinin düzenli olarak girilmesi sağlık bilgilerinin takibi açısından önemlidir. 
2- Güncel Boy (cm): Boy bilgisi ekranı, çocuğun tarih seçimi ile birlikte boy bilgisinin girildiği ekrandır. Boy bilgisi seçeneği tıpkı kilo bilgisindeki gibi çocuğun cinsiyet ve yaş bilgisine göre ortalama bir aralıkta açılarak kullanıcıya seçim için kolaylık sağlar. Boy bilgisinin düzenli olarak girilmesi, sağlık bilgilerinin takibi açısından önemlidir.

3- Güncel Vücut Sıcaklığı: Şekil 5.b'deki ateş bilgisi ekranı, tarih seçimi ile birlikte çocuğun anlık ateş bilgisinin istendiği ekrandır. Ateş bilgisi seçeneği $37.4 \mathrm{oC}$ ortalama bir derece olarak açılır ve seçim için kolaylık sağlar. Ateş bilgisinin girilmesi, ASYE kökenli çocuk hasatlıklarının teşhisi ve takibinde en önemli bilgilerden biridir. Ek olarak, çocuğun daha önce havale geçirip geçirmediğinin bilgisi de bu ekranda alınır.

4- Güncel Gözlemlenen Semptomlar: Şekil 5.c'de semptomlar ekranı gösterilmiştir. Çocuğa ait anlık olarak gözlemlenen mevcut her bir semptomun "Hafif”, "Orta” ve "Şiddetli” olarak seçilebildiği ekrandır. Bulguların hafif, orta ve şiddetli olması, söz konusu bulgunun majör ve minör bulgu olarak ayırt edilmesinde önemlidir. Halsizlik, baş ağrısı, burun akıntısı, burun tıkanıklığı, öksürük, hapşırma, ses kısıklığı, boğaz ağrısı, göz kızarıklığı/gözde sululuk, iştahsızlık, kas ağrısı, eklem ağrısı, eklemlerde şişlik, boyun bölgesinde şişlik, kusma yutma zorluğu, ağız kokusu, sarılık ve kulak ağrısı olarak toplamda 19 tane semptom bulunmaktadır.

5- Genel Durum: Semptomlardan sonra bazı sorular kullanıcıya sorulmaktadır. Bunlardan ilki, genel durum ekranıdır. Çocuğun o andaki genel durumu hakkında bilgi toplamamızı sağlayan bu ekranda, hastanın genel durumu "İyi”, “Orta” ve "Kötü” olarak seçimler sağlayan ekrandır.

6- Aktivite Durumu: Çocuğun o anda ki aktivite durumu hakkındaki bilginin toplanmasına olanak verir. Aktivite durumu; “Aktivitesi Azalmadı”, “Ateşsiz Zamanlarda İyi”, “Ateşliyken Bitkin ve Sürekli Halsiz" olmak üzere üç seçenek sunar.

7- Nesnelere ve İnsanlara Yönelik Verdiği Reaksiyonlar: Nesne ve insanlara yönelik verdiğ reaksiyonlar ekranı; "Normal”, "Uykuya Meyilli” ve "Sürekli Uyku Hali” olmak üzere üç seçenekten oluşur.

8- Beslenme Aktivitesi: Şekil 5.d'de beslenme aktivitesi ekranı gösterilmiştir. Bu ekran, "Beslenmesi Bozulmamış", "İşstahsız Ama Beslenebiliyor" ve "Beslenemiyor, Çok İştahsız" olmak üzere üç seçenek sunmaktadır.

9- Duygusal Değişimler: Duygusal değişim ekranı, "Huzursuz" ve "Sakin” olmak üzere iki seçenekten oluşmaktadır.

10- Solunum Sıkıntısı ve Hırıltı: Solunum sıkıntısı ekranı, "Solunum Sikıntısı Yok" ve “Güçlükle Nefes Alıyor” şeklinde iki seçenekten oluşmaktadır. 
11- Ciltte veya Dudaklarda Morarma: Ciltte veya dudaklarda morarma ekran1, "Var" ve "Yok" seçeneklerini içermektedir.

12- Cilt Döküntüsü: Ciltte döküntü ekranı, "Var" ve "Yok" seçeneklerini içermektedir.

13- Mevcut Kullanılan İlaçlar ve Zamanı: Mevcut kullanılan ilaçlar ve zamanı ekranı "Parasetamol" ve "Ibuprofen" olmak üzere iki seçenekten oluşur. Fakat hastanın kullandığı farklı bir ilaç var ise, alt bölümde bulunan "Ekle" butonundan ilaç eklenebilir. İlaç seçimi yapıldıktan sonra, ilacın veriliş zamanı bilgisi istenmektedir.

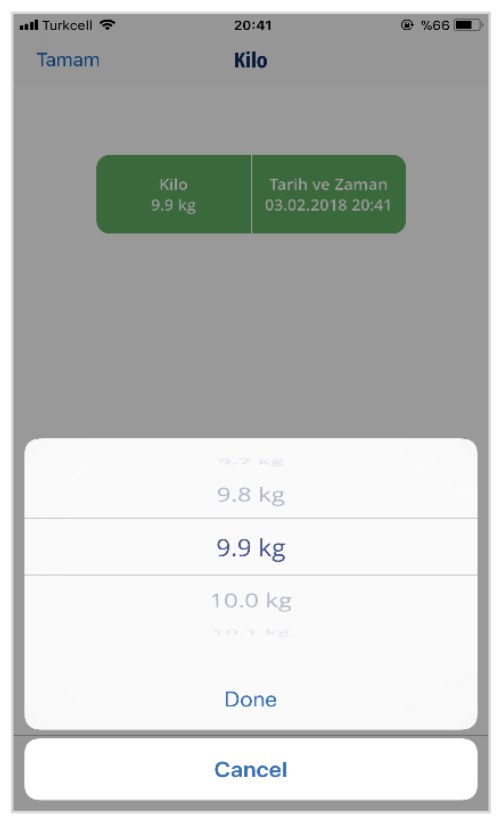

a) Kilo bilgisi giriş ekranı

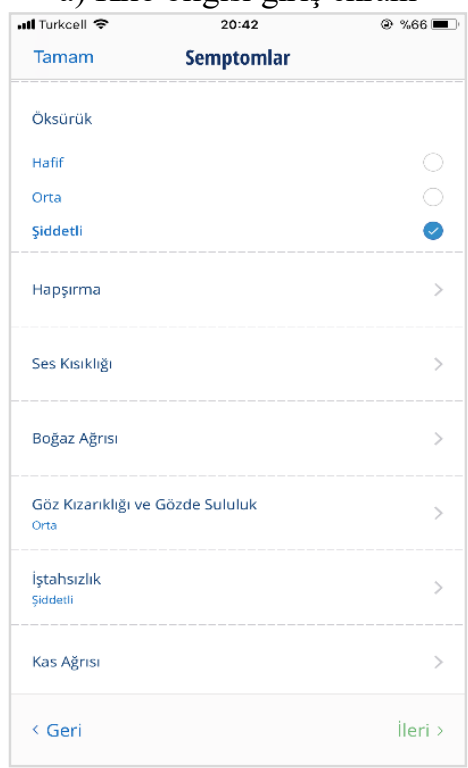

c) Semptomlar giriş ekranı

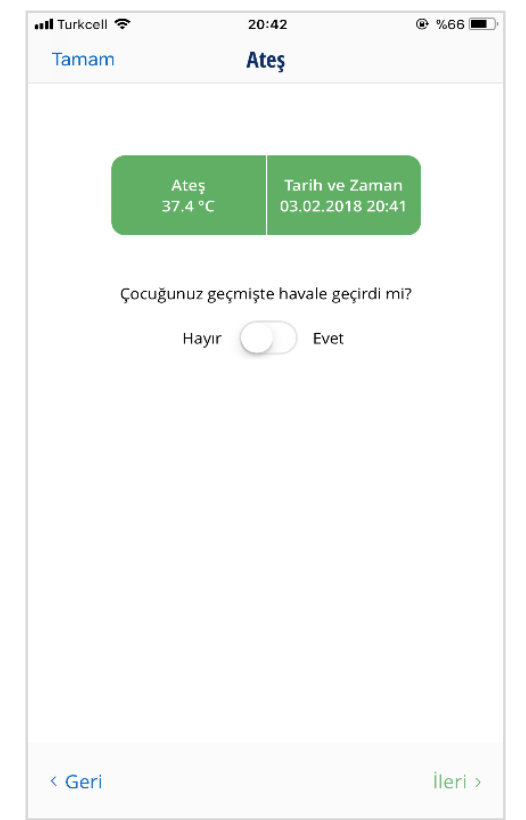

b) Ateş bilgisi giriş ekranı

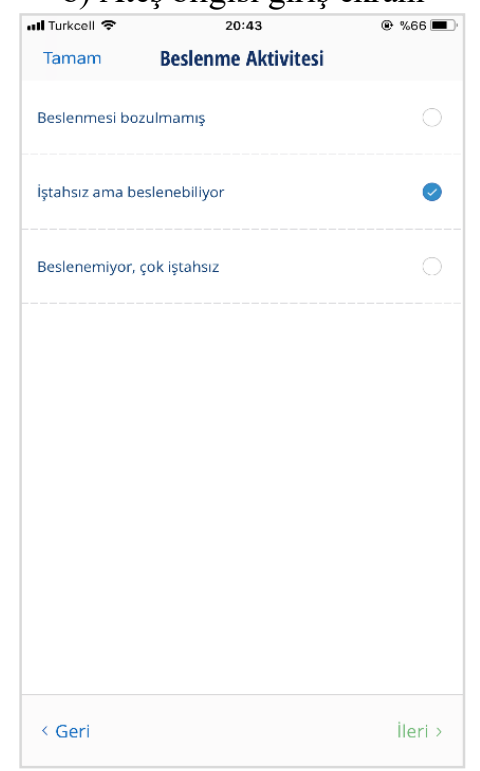

d) Beslenme durumu ekranı

Şekil 5. TrackARTI mobil uygulamasının güncel kilo, güncel vücut sıcaklığı, güncel gözlemlenen semptomlar ve beslenme aktivitesinin toplandığı alt menüler. 
14- Güncel Uygulanan Tıbbi Destek Adımları: Uygulanan tıbbi destek adımları ekranı, “Soğuk Duş Uygulaması, "Soğuk Havlu Uygulaması” ve “Ateşli Havale İçin Tedavi” olmak üzere üç seçenekten oluşur. Kullanıcı, çocuğu için farklı bir tedavi uygulamış ise alt bölümde bulunan "Ekle" butonundan bu bilgiyi girebilir. Seçim yapıldıktan veya "Ekle" butonu ile yeni uygulama adı listeye eklendikten sonra, uygulamanın yapılma zamanı bilgisi istenmektedir.

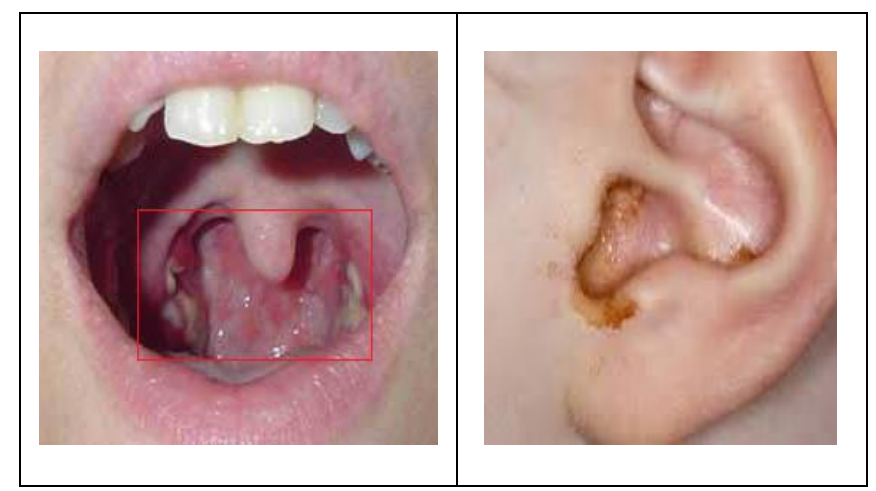

Şekil 6. Akıllı telefon kamerası ile hastadan boğaz /bademcik ve kulak görüntülerinin toplanması.

15- Kulak Fotoğrafları: Kulak fotoğrafları ekranı, çocuğun dış kulak fotoğraflarını çekmek içindir (Şekil 5). Toplamda 4 adet kulak fotoğrafı eklenebilir. 2 adet sol kulak ve 2 adet sağ kulak fotoğrafı çekilmesi önerilir. Alt bölümde bulunan "Ekle" butonu ile TrackARTI uygulaması içerisinden cihazın fotoğraflar albümünden mevcut kulak görüntüleri seçilerek eklenebilir. Bu safhada, pediatrist/ebeveyn isterse bir adet mobil tabanlı otoskop başlik aparatını [14,15] telefon kamerası önüne takabilir (opsiyonel) ve kulak iç görüntülerini de toplayabilir. Dolayısıyla, sistem kulak iç/dış yüzey görüntü verilerini uygulama içerisinden toplamaya olanak sağlamaktadır.

16- Boğaz ve Bademcik Fotoğrafları: Boğaz ve bademcik fotoğrafları ekranı, çocuğun boğaz fotoğraflarını çekmek içindir (Şekil 5). Toplamda 2 adet boğaz fotoğrafi eklenebilir. Alt bölümde bulunan "Ekle" butonu ile TrackARTI uygulaması içerisinden cihazın fotoğraflar albümünden mevcut boğaz görüntüleri seçilerek eklenebilir. Bu safhada, pediatrist/ebeveyn isterse, bir adet mıknatıslı/magnetik lens mercek başlık aparatını telefon kamerası önüne takabilir [16] ve boğaz içi görüntüleri daha net şeklide toplayabilir. Fotoğraf çekimleri uygulama içerisinden yapılmaktadır. 15 ve 16.nc1 maddelerdeki toplanan fotoğraflar ile, hastaların kulak veya boğaz bölgelerinde gözlemlenen Üst Solunum Yolu Enfeksiyonu (ÜSYE) hastalıklarına bağlı; hastanın zaman ilişkisel iyileşme faktörü hesaplama, hastalığın derecelendirilmesi, kullanılan ilaçların etkileri, yaşa göre hastalık dönemlerine ait imgesel desenler, vb. anlamlı bilgilerin, görüntü işleme çıkarım mekanizması ile elde edilmesi mümkündür. 
Tablo 1. TrackARTI ve benzer m-sağlık projelerinin temel kriter ve fonksiyonlara göre kiyaslanması.

\begin{tabular}{|c|c|c|c|c|}
\hline Temel Kriter ve Fonksiyonlar & 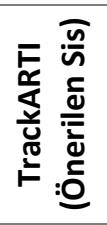 & 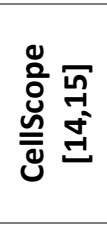 & 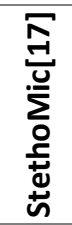 & 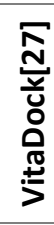 \\
\hline $\begin{array}{l}\text { Muayene sırasında dijital bir ön-muayene teşhis ve takip kartı } \\
\text { içermesi. }\end{array}$ & + & + & - & - \\
\hline $\begin{array}{l}\text { Akıllı telefon kamerası (mobil-entegre kamera lens aparatı } \\
\text { seçeneğiyle) boğaz/ bademcik görüntülerinin kaydedilmesi }\end{array}$ & + & - & - & - \\
\hline $\begin{array}{l}\text { Kulak yüzeyinin veya kulak zarının enfeksiyon görüntülerini akıllı } \\
\text { telefon kamerası veya bir adet mobil-entegre otoskop cihazı } \\
\text { kullanım seçeneği ile kaydedilmesi. }\end{array}$ & + & + & - & - \\
\hline $\begin{array}{l}\text { Akıllı telefon kamerasıyla çocuğun genel solunum ve tepkilerinin } \\
\text { gözlenmesi açısından genel vücut görünümüne dair bir video verisi } \\
\text { (10 saniye) kaydedilmesi. }\end{array}$ & + & - & - & - \\
\hline $\begin{array}{l}\text { Vücut sıcaklığının, bir kızıl ötesi termometre cihazı veya } \\
\text { doğrulanmış diğer bir ateş ölçer ile ölçülüp ateş verisinin } \\
\text { otomatik/manuel olarak kaydedilmesi. }\end{array}$ & + & - & - & + \\
\hline Akciğer solunum sesi kayıtları kaydedilmesi. & - & - & + & - \\
\hline $\begin{array}{l}\text { Sistemden hasta hakkında aylık ve yıllık bazda genel bir } \\
\text { değerlendirme sunulması. }\end{array}$ & + & + & + & - \\
\hline $\begin{array}{l}\text { Kayıtlı çocuk hekimi ile anında mesajlaşma ve konsültasyon } \\
\text { ortamı. }\end{array}$ & + & - & - & - \\
\hline $\begin{array}{l}\text { 0-6 yaş grubu çocuk hastalarda hastalık iyileşme faktörünün } \\
\text { çıkarılması. }\end{array}$ & + & - & - & - \\
\hline $\begin{array}{l}\text { Yukarıda belirtilen } 18 \text { farklı tıbbi verinin bir anda bir dijital ön- } \\
\text { muayene kartı üzerinden toplanması, saklanması, yetkili kişilerle } \\
\text { anlık paylaşılması. }\end{array}$ & + & - & - & - \\
\hline $\begin{array}{l}\text { Teşhis ve takip destek için Yapay Zekâ Çıkarım Mekanizması ve } \\
\text { Anlamsal Veb Tabanlı Kural Bilgi tabanını içermesi. }\end{array}$ & + & - & - & - \\
\hline $\begin{array}{l}\text { Teşhis ve takip destek için anlık Görüntü İşleme Mekanizması } \\
\text { içermesi. }\end{array}$ & + & + & - & - \\
\hline $\begin{array}{l}\text { Zamanla toplumdaki } 0-6 \text { yaş grubu çocuk hastalar için hastalık } \\
\text { yayılma derecesi, insidansı, artış hızı ve epizot hızı vb. toplumsal } \\
\text { sağlık demografisi hakkında istatiksel bilgi üretme potansiyeline } \\
\text { sahip olması. }\end{array}$ & + & $+/-$ & $+/-$ & - \\
\hline $\begin{array}{l}\text { Zamanla, hastalıklarda ilaç kullanımına ilişkin kişisel veya } \\
\text { toplumsal bazda istatistik bilgi üretme potansiyeline sahip olması. }\end{array}$ & + & - & - & - \\
\hline $\begin{array}{l}\text { Yeni bilgiler çıkarsamak için sürekli medikal veri toplanması ve } \\
\text { otomatik olarak belgelenmesini sağlayabilmesi. }\end{array}$ & + & + & + & + \\
\hline $\begin{array}{l}\text { Platformdan bağımsız çalışabilmesi; Veb, Tabletler, IOS telefonlar, } \\
\text { Android telefonlar vs. }\end{array}$ & + & - & + & - \\
\hline
\end{tabular}

17- Genel Görünüm Videosu: Genel görünüm videosu ekranı, çocuğun yüz ve vücut olarak genel görünümünü video verisi olarak kayıt etmek içindir. Maksimum 1-2 dakikalık bir video çekilmesi önerilir. $\mathrm{Bu}$ süre isteğe bağlı artabilir. Alt bölümde bulunan "Ekle" butonu bölümünden, uygulama içerisinden video çekimi sağlanmaktadır.

18- Muayene Not Alanı: Not alanı, kullanıcının o anki açılan kart için bırakmak istediği özel mesaj/not için ayrılan bölümdür. Not alanına bilgi girilmesi zorunlu değildir. 
Tablo 1'de diğer benzer projeler ile TrackARTI sisteminin katkıları bakımından kıyaslaması gösterilmektedir. Sonuç olarak, yukarıda bahsi geçen 18 farklı medikal verinin zaman içerisinde birikmesiyle, kişiye özgü veya toplum bazında, çocuk hastalarda gözlemlenen hastalık türleri, görülme sıklı̆̆ı, hastalıkların iyileşme süreleri (haftalık, aylık veya yıllık bazda), her atlatılan/mevcut hastalık için sıkça görülen semptomlar ve şiddetleri, kullanılan ilaçlar ve miktarları, uygulanan tedavi destek adımları vb. istatiksel verilerde elde edilir. Aynı zamanda, bu veriler, sistemin çıkarım mekanizmasında işlem görerek, zaman-mekândan bağımsız ihtiyaç doğrultusunda hastaya özgü anlık tedavi destek süreci önermesi gibi faydalı bilgileri türetilebilir.

\section{ONTOLOJİ BİLGI TABANI VE ÇIKARIM KURALLARI}

Sistemin ontolojisi, ASYE kökenli alt ve üst solunum yolu enfeksiyonlarına yol açan hastalıklara ait kavramlar, kavramlar arası ilişkiler, özellikler ve kavramlara ait veri ögelerinin tanımlanması ile oluşturulmuştur. TrackARTI ontolojisi, Protégé editör [33] kullanılarak OWL dilinde geliştirilmiştir (bkz. OWL dosyasının bir kesiti Tablo 2'de verilmiştir).

Ontoloji oluşturulurken, OWL dilinin, owl:class, rdfs:subClassOf, owl:DatatypeProperty, owl:ObjectProperty vb. gibi anlamsal etiketleri kullanılmıştır. TrackARTI ontolojisi, bir çocuk vakaya ait profil bilgisine yönelik kavramlar (örneğin; güncel yaş, kilo, cinsiyet, boy vb. veriler ile geçmiş verileri), semptomlar ve türlerine yönelik kavramlar (örneğin; vücut sıcaklığı, cilt döküntü/morarma, beslenmesi, belirtileri, solunum fonksiyonları vb.), semptomlara ait derecelendirme kavramları (örneğin; hafif, orta, şiddetli semptomların sayısı), ilaç bilgilerine yönelik kavramlar, zaman kavramları, hastalık kavramları, tedavi destek süreç kavramları, aktivite durumu, genel durumu vb. oluşumlara ait kavramlar, karamlar arası ilişkiler ve ilgili veri öğelerini içermektedir.

Bu kavramlar, özellikler, veri öğeleri vb. ontoloji birimlerine bağlı kurallar oluşturulmasıyla, sistemin Anlamsal Veb Kural Tabanı ortaya çıkmış ve bu sayede kullanıcılarına uygun kural(lara) göre önermeler sunabilmesi sağlanmıştır. İlaveten, kişiye özgü hasta olma sıklı̆ğ, gözlenen hastalık türleri ve hızı (aylık vb.), hangi hastalıkta en çok hangi semptomlara rastlandığ

$\mathrm{Bu}$ çalışma kapsamında, TrackARTI ontolojisi geliştirilmiş, üzerinde 96 adet Anlamsal Veb Tabanlı Çıkarım Kuralı medikal kural olarak tanımlanmış, kayıtlı bir hasta hakkında anlık yeni medikal veriler çıkarsaması veya öneriler oluşturulması sağlanmıştır. Sistemin yapay zekâ kuralları, Anlamsal Veb Kural Dili (Semantic Web Rule Language - SWRL) [34] ile 
oluşturulmuştur. SWRL, OWL üzerine temellendirilmiş, tümdengelim özelliğine sahip güçlü bir kural tanımlama dilidir.

Tablo 2. TrackARTI OWL Ontoloji Bilgi Tabanından bir kesit.

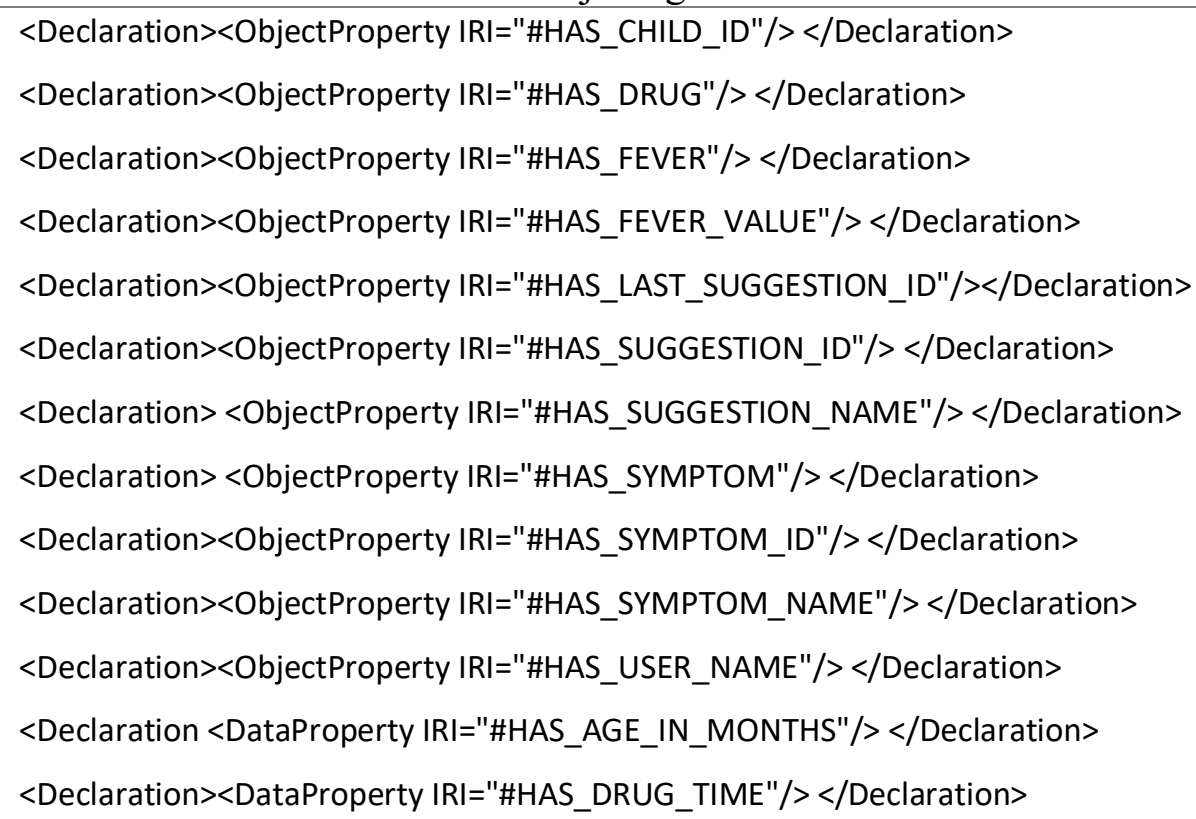

Bir hastada AOM taranmasına yönelik oluşturulmuş bir kural aşağıda sunulmuştur. Kural, hastanın bazı verileri tarayıp önceden tanımlı koşullara ve sınır değerlerine göre kıyaslayıp doğrulaması durumunda "Case: Recurrent Otitis Media" soncunu üretecektir. Kural içinde taranan veriler: son ölçülen vücut sıcaklığı, son verilen ilaçlar ve zamanı, güncel yaş bilgisi ve son yılda tekrarlanan kulak AOM hastalığı sayısıdır.

If (temp>37.4 \& temp>38.1 \& Drug Is Given (true) \& Drug Time Last One Hour (true), Has Age in Months $>12 \&$ Number of AOM Year $>4 \rightarrow$ "Case: Recurrent Otitis Media" sonucuna varır ve TrackARTI "Kulak Burun Boğaz Uzmanına Gitmelisiniz." önermesini döndürür.

Bu kuralın SWRL yapısı aşağıdaki gibidir:

Rule: USER_ID (?uid), HAS_CHILD_ID (?uid, ?cid), NUMBER_AOM_YEAR (?cid, ?aom), greaterThan (?aom, "4"^^^int), HAS_TEMPERATURE (?cid, ?t), greaterThan (?t, "37.4"^^double), lessThan (?t, "38.1"^^double), HAS_AGE_IN_MONTHS (?cid, ?months), greaterThan (?months, 12) $\rightarrow$ HAS_CASE(?cid, CASE77)

Bir çocuğun son bir yılda en az 4 defa AOM olması durumunda, sistem "Tekrarlayan Otitis Media" teşhisini (CASE 77) tanımlar, bu nedenle önerme istendiğinde "Kulak Burun Boğaz Uzmanına Gitmelisiniz." şeklinde önerme sunulmaktadır. 
Benzer şekilde, yılda en az 4 defa akut sinüzit geçiren çocuklar için "Rekürren Sinüzit" teşhisi ile "Kulak Burun Boğaz Uzmanına Gitmelisiniz." şeklinde önerme yapılmaktadır.

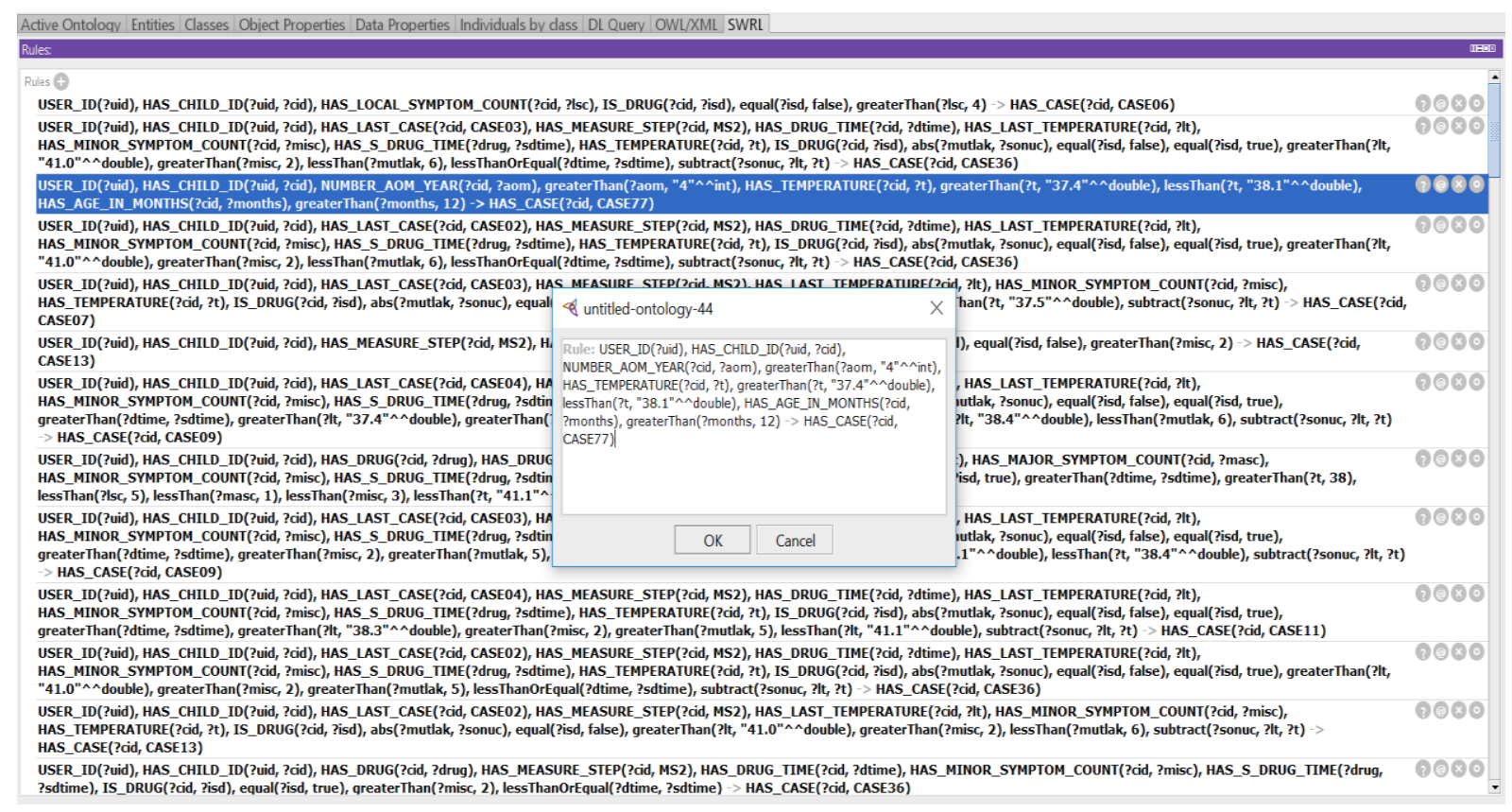

Şekil 7. Anlamsal Veb Kuralı Bilgi Tabanı (96 kural).

Diğer bir kural ise, çocukların boylarının yıla göre takibini yapan kurallar tanımlanmıştır. Örneğin bir vakanın boy bilgisinde yılda 4,5 cm'den daha az artış görülürse "Endokrin Uzmanına Gitmelisiniz." şeklinde önerme yapılmaktadır. Yukarıdaki örneklerden anlaşıldığ 1 üzere, sistemin kural tabanında değişken veriler ve çeşitli koşullar dikkate alınarak kural tabanı oluşturulmuştur. Kural bilgi tabanı, ASYE kökenli bazı hastalıklara ait 96 farklı medikal kuralı içermektedir (Şekil 7). Kural tabanı zamanla gelişmekte ve pediatri uzmanlarının sisteme katkılarıyla her geçen gün mevcut kural sayısı artmaktadır. Hemen hemen tüm kurallarda dikkate alınan veriler:

— Hastanın profil bilgisi (güncel yaş, kilo, cinsiyet, boy vb. veriler ile geçmiş verileri),

— Son ölçülen vücut sıcaklığg1,

— Muayene sırasında gözlemlenen majör, minör ve lokal semptomların sayısı (örneğin; hafif, orta, şiddetli semptomların sayısı),

- Son verilen ilaçlar ve zamanı,

- Eğer uygulanmışsa, en son uygulanan tıbbi destek tedavi süreçleri ve zamanı (soğuk uygulama, soğuk duş vb.),

— Eğer mevcut ise, kulak ve boğaz iltihabı vb. geçmiş AOM veya Aut Sinüzit sayısı vb. ve hastaya ait anlık medikal verilerin, veri tabanından ontolojiye anlık olarak aktarılması ve 96 kuraldan vakaya uygun olanların HAS_CASE (Şekil 8) şeklinde çekilmesi sağlanmaktadır. 
Çekilen çıkarım verileri, hekime/ebeveyne karar destek mekanizması olarak karar sürecinde yardımcı olabilmektedir.

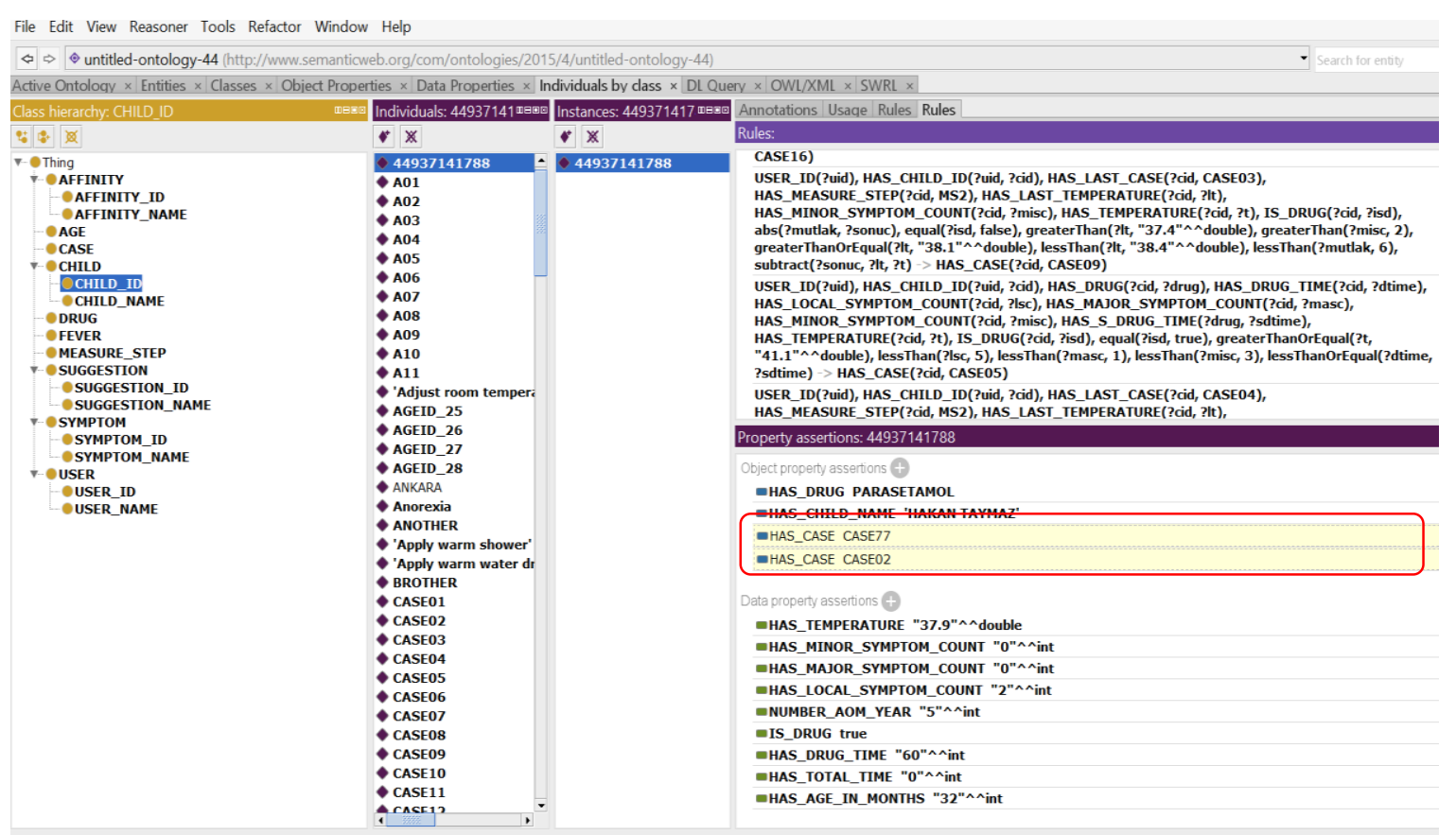

Şekil 8. Anlamsal Veb Kuralı Bilgi Tabanının çıkarım sonucunu gösteren bir örnek.

Şekil 8'de görüldüğü üzere, "Hakan Taymaz" adlı 32 aylık bir çocuk hastanın, 2 lokal semptomu ön-muayene kartından okunmuştur. $60 \mathrm{dk}$ öncesinde "Parasetamol" türevi olarak bir ilaç verilmiş ve son bir yılda tekrarlayan kulak iltihabı sayısı 5 olarak kayıt edilmiş olan bu vakaya; sistem, CASE 2 ve CASE 77'yi çıkarsama sonucu olarak atamıştır (Şekil 8'de çizgili bölge). Ontolojide, öneriler (Suggestions) SG kodu ile yaratılmıştır. Ontolojide toplam 21 adet öneri tanımlanmıştır.

CASE 2'ye ait ilişkilendirilmiş öneriler SG 6, SG 7, ve SG 12'dir. CASE 77'ye ait sadece SG 80 önerisi bulunmaktadır.

\section{CASE 2'ye bağlı öneriler:}

$\rightarrow$ SG 6: Oda sicaklığını ayarlayın.

$\rightarrow$ SG 7: Çocuğun kıyafetlerini çıkarın ve çıplak bırakın.

$\rightarrow$ SG 12: Vücut sicaklığını tekrar 1⁄2 saat sonra ölçün.

\section{CASE 77'ye bağlı öneriler:}

$\rightarrow$ SG 80: Kulak Burun Boğaz uzmanına gitmelisiniz.

Yukarıdaki vaka için, sistem, önermeleri toplam 4 adet olarak yukarıdaki gösterildiği gibi çıkarsamıştır. 


\section{5. ÇIKARIM MOTORUNUN GELISTTÍRİLMESI}

Veb servisleri vasıtasıyla SWRL kurallarını çalıştırmak için açık kaynak bir OWL DL (Description Logic) tabanlı çıkarım motoru olan Pellet Uygulama Programlama Ara yüzü (PELLET API) [35] kullanılmıştır. Java ortamında, OWL API [36] ve Pellet API kütüphaneleri, Tablo 3'te 1-4 satırlarındaki gibi içe aktarılarak sistemin ontolojisi üzerinde çıkarım sağlanmıştır. Çıkarım sonucu olarak her bir kural ve ona bağlı her öneri, çıkarım sırasında Java değişkenlerine aktarılır. Çıkarım sonuçları, Java Komut Dosyası Nesnesi Gösterimi (JSON) [37] biçimine dönüştürülür ve daha sonra veri iletimi RESTful Veb servisleri [38] üzerinden mobil ortama alınır.

Tablo 3. Çıkarım Mekanizması Prosedürü.

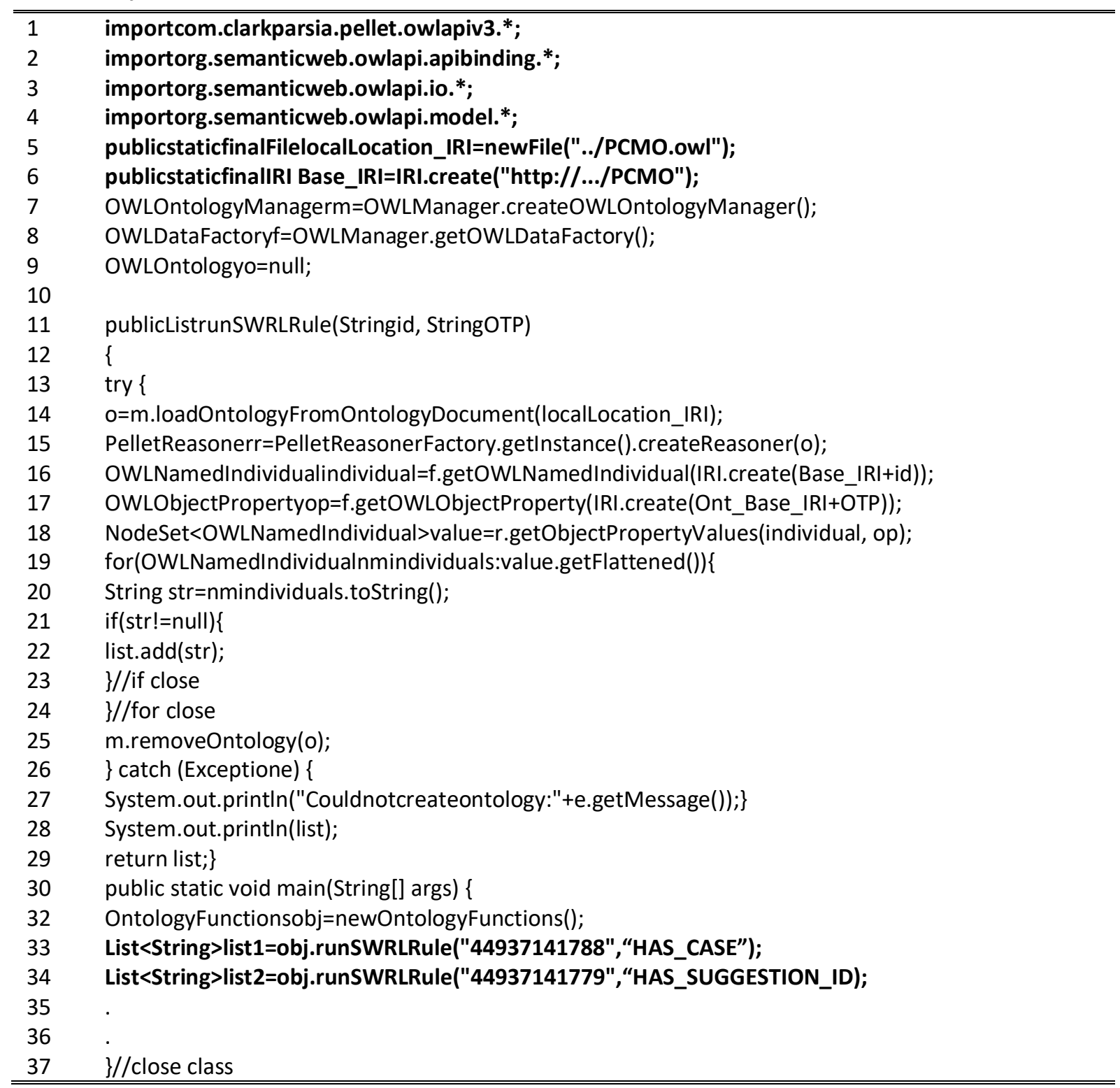


Şekil 8'de gösterilen "Hakan Taymaz" (id: 44937141788) vakası için çıkarım işlemi uygulanmıştır. Ontolojideki SWRL kurallarını çalıştırmak için, Java ortamından bu hastaya ait eldeki toplanan verileri anlık gömerek çıkarım sağlamaya ait ilgili kod Tablo 3' te verilmiştir. Yukarıdaki "Hakan Taymaz" vakası için Tablo 3'te 38-39.ncu satırlarda bulunan runSWRLRule işlevi çalıştırılmıştır. Bu fonksiyonun 2 parametresi bulunmaktadır. İlk parametre hastanın kimliğidir ("44937141788"). İkinci parametre, ontolojideki hangi özelliğe ait çıkarım sonucunun çekileceğidir. Tablo 3'ün 33.ncü satırında "HAS CASE" özelliği için runSWRLRule fonksiyonu çalışmıştır. Bu vaka için, ontoloji üzerindeki 96 adet SWRL kurallarından uygun olanlarına ait "HAS CASE" özelliğine bağlı CASE numara/numaraları çekilmektedir. Ayrıca, 34.ncü satırda, çekilen CASE numarasına bağlı olan "HAS SUGGESTION ID" özelliği ile ilişkilendirilmiş SG değerleri çekilmektedir. Vaka için, "HAS CASE" ve "HAS SUGGESTION ID" özelliklerinin sonuçları, Java değişkenleri olan List 1 (CASE 02, CASE77) ve List 2 (SG6, SG7, SG12, SG80)'ye aktarılmıştır.

\section{SONUÇLAR}

$\mathrm{Bu}$ makalede, 0-6 yaş grubu çocukluk döneminde sıklıkla rastlanan Akut Solunum Yolu Enfeksiyonları (ASYE) hastalıklarının takibine yönelik geliştirilmiş Uzaktan Medikal Takip Mobil Sistemi (TrackARTI) önerilmiştir. TrackARTI’nın temel amacı, ASYE dönemlerindeki çocuk hastalara ait gerçek verileri çeşitli ortamlarda anlık olarak toplamak, istenildiğinde görüntülemek, makinelerin anlayacağı şekilde yapısal formda saklamak, sistemin kendi çıkarım mekanizması sayesinde yorumlayıp kişiye özgü önermeler yapmak veya çıkarsınmış ilgili yeni bilgileri kullanıcılarına sunmaktır. TrackARTI sisteminin kullanıcıları ebeveynler, pediatri uzmanları ve ilgili sağlık personelidir.

TrackARTI sisteminin; bir adet TrackARTI Yapay Zekâ Çıkarım Mekanizması ve bir adet TrackARTI Mobil Uygulaması olmak üzere, iki temel çıktısı bulunmaktadır. Yapay Zekâ Çıkarım Mekanizması modülü kendi içinde iki temel aşamayı içermektedir; 1) Medikal Görüntü İşleme ile çıkarımlar (elde edilen medikal görüntü verileri üzerinden) ve 2) Anlamsal Veb Çıkarım Kuralları ile yeni verilerin ve önermelerin çıkarsaması.

TrackARTI Mobil Uygulaması ile, kullanıcılar tarafından açılan bir adet ön-muayene kartında, bir vakaya ait anlık gözlemlenen çeşitli türdeki 18 farklı verinin toplanması, saklanması ve yetkili kişilerle paylaşılmasını sağlanabilmektedir. 
Geliştirilen TrackARTI ontolojisi üzerinde, 96 adet medikal Anlamsal Veb Kuralı tanımlanmış ve kayıtlı bir hasta hakkında anlık yeni medikal veriler çıkarsaması ve anlık medikal öneriler sunulması sağlanmıştır.

Önerilen TrackARTI sistemi günümüz akıllı M-Sağlık sistemlerine bir örnek teşkil etmektedir. Yapay Zekâ Çıkarım Mekanizması sayesinde ebeveynlere ve ilgili sağlık ekibine 0-6 yaş grubundaki çocukların hastalık dönemlerinde yardımcı olacak bazı tedavi destek önerileri sunulabilmektedir. İlaveten, her vaka için bir hastalığın yaşanma sıklığı, belli zaman aralığında (günlük, haftalık, aylık, yıllık vb.) gözlemlenen tüm hastalık türleri ve sıklığı, gözlemlenen her hastalı türü için sıkça görülen semptomlar vb. veriler ile anlamsal bilgiler çıkarsayabilmektedir. Son olarak, hastaya, uzmana ve ebeveyne sağladığı faydaların yanı sıra; zamanla, bir toplulukta/toplumdaki 0-6 yaş grubu hastalarda gözlemlenen hastalık yaygınlığg, insidansı, saldırı hızı ve epizot hızı vb. bilgilerin çıkarımı sayesinde toplumun sağlık demografisi hakkında önemli bilgiler de elde edilebilmektedir.

Bu makale, TrackARTI sisteminin, yalnızca TrackARTI App'ı ve Anlamsal Veb Kuralı Tabanlı Çıkarım mekanizması üzerine yoğunlaşmıştır. Sitemin medikal görüntü işleme mekanizmasını (elde edilen medikal görüntü verileri üzerinden çıkarım sağlanması) oluşturan modül, henüz tamamlanmadığından, bu kısım gelecek makale çalışmasında anlatılacaktır. Ayrıca, mevcut uygulama ile 100 hasta için saha çalışmaları henüz başlamış olup değerlendirme sonuçları gelecek makale çalışmasında sunulacaktır. TrackARTI halen devam eden bir proje olup, mevcut sağlık sistemine uyum çalışmaları konusunda çeşitli geliştirme ve test çalışmalarına devam etmektedir. Sistemin geliştirilmeden önceki taslak hali IEEE kaynaklı bir çalıştayda [39] sunulmuştur.

\section{KAYNAKLAR}

[1] Cajita, M.I., Gleason, K.T. and Han, H.R. A systematic review of mHealth-based heart failure interventions. The Journal of cardiovascular nursing, (2016), 31(3), p.E10. doi:10.1089/tmj.2014.9997.

[2] Alepis E, Lambrinidis C. M-Health: supporting automated diagnosis and electronic health records, Springer Plus. (2013); 2:103. Doi: 10.1186/2193-1801-2-103.

[3] Mohammadzadeh N, Safdari R. Patient Monitoring in Mobile Health: Opportunities and Challenges, Medical Archives. (2014); 68(1):57-60. doi:10.5455/medarh.2014.68.57-60.

[4] Lee J, Rho MJ. Perception of Influencing Factors on Acceptance of Mobile Health Monitoring Service: A Comparison between Users and Non-users, HealthCare Informatics Research. (2013); 19(3):167-176. doi:10.4258/hir.2013.19.3.167.

[5] Free C, Phillips G, Galli L, et al. The Effectiveness of Mobile-Health Technology-Based Health Behaviour Change or Disease Management Interventions for Health Care Consumers: A Systematic Review, Cornford T, ed. PLoS Medicine. 2013; 10(1):e1001362. doi:10.1371/journal.pmed.1001362. 
[6] Davey S, Davey A, Singh JV. Mobile-Health Approach: A Critical Look on Its Capacity to Augment Health System of Developing Countries, Indian Journal of Community Medicine : Official Publication of Indian Association of Preventive \& Social Medicine. (2014); 39(3):178-182. doi:10.4103/0970-0218.137160.

[7] Petersen C, DeMuro P. Legal and Regulatory Considerations Associated with Use of PatientGenerated Health Data from Social Media and Mobile Health (mHealth) Devices, Applied Clinical Informatics. (2015); 6(1):16-26. Doi: 10.4338/ACI-2014-09-R-0082.

[8] Klasnja P, Pratt W. Healthcare in the Pocket: Mapping the Space of Mobile-Phone Health Interventions, Journal of Biomedical Informatics. (2012); 45(1):184-198. doi:10.1016/j.jbi.2011.08.017.

[9] Germanakos P, Mourlas C, Samaras G. A mobile agent approach for ubiquitous and personalized eHealth information systems, In: Proceedings of the Workshop on 'Personalization for e-Health' of the 10th International Conference on User Modeling (UM'05); (2005). p. 67-70.

[10] Baysari MT, Westbrook JI. Mobile Applications for Patient-centered Care Coordination: A Review of Human Factors Methods Applied to their Design, Development, and Evaluation, Yearbook of Medical Informatics. (2015); 10(1):47-54. DOI: 10.15265/IY-2015-011.

[11] Research-2-Guidance. mHealth App Developer, Economics 2014. Germany: research2guidance; (2014).

[12] Akşit S. Akut Solunum Yolu Enfeksiyonları - 1, Ege Üni. Tip Fak. Çocuk Sağlığı ve Hastalıkları, STED 2002, (2002), 11(4), 132-135, http://www.ttb.org.tr/STED/sted0402/akut.pdf, Last accessed: 30 April 2017.

[13] Koturoğlu, G., Çocuklarda Üst Solunum Yolu Enfeksiyonlarl, Upper Respiratory Tract Infections in Children. The Journal of Pediatric Research, (2015);2(2):62-5. DOI: 10.4274/jpr.65365, http://cms.galenos.com.tr/FileIssue/16/820/article/62-65.pdf, Last accessed: 30 April 2017.

[14]Cellscope, iPhone otoscope Project, http://mobihealthnews.com/17598/cellscope-smartphonediagnostic-startup-raises-1m/, Last accessed: 30 April 2017.

[15]Brian Dolan, CellScope, smartphone diagnostic startup, raises $\$ 1 \mathrm{M}$, June 11, 2012, http://www.mobihealthnews.com/17598/cellscope-smartphone-diagnostic-startup-raises-1 m/, Last accessed: 30 April 2017.

[16] Magnetic iPhone and Android Lens Series, https://photojojo.com/awesomeness/cell-phone-lenses. Last accessed: 30 Jan 2016.

[17]Leng S, Tan R S, Tshun K, Chai C, Wang C, Ghista D, and Zhong L, The electronic stethoscope: Stethocloud, BioMedical Engineering OnLine. (2015); 14(1), 07, 66 pages. DOI:10.1186/s12938015-0056-y

[18] Mobile Stethoscope, http://mobilestethoscope.com/, Last accessed 30 April 2017.

[19]3M Littmann Range, http://www.littmann.com, Last accessed: 30 April 2017.

[20]Welch-Allyn Elite Electronic Stethoscope, Last accessed: http://www.welchallyn.com, Last accessed 30 April 2017.

[21]Cardionics E-scope II, http://www.cardionics.com, Last accessed: 30 April 2017.

[22] RijuvenCardioSleeve, http://rijuven.com/cardiosleeve.html Last accessed: 30 April 2017.

[23] Ekoscope, http://www.ekoscope.com/, Last accessed 30 April 2017.

[24] ViScope, http://www.cardionics.com/clinical-vi-scope.html, Last accessed: 30 April 2017.

[25] SensiCardiac, https://www.sensicardiac.com/, Last accessed: 30 April 2017.

[26] Thinklabs, http://www.thinklabs.com, Last accessed: 30 April 2017. 
[27] VitaDock, http:// www. vitadock.com/ vitadock.html Last accessed: 30 April 2017.

[28] Berners-Lee T, Hendler J and Lassila O. The Semantic Web, Scientific American. May (2001); 2937.

[29] Gruber, T. Ontology, Encyclopedia of Database Systems (Springer-Verlag). Liu, Ling; Özsu, M. Tamer, eds. ISBN 978-0-387-49616-0. http://tomgruber.org/writing/ontology-definition2007.htm, (2008), Last accessed: 30 April 2017.

[30]Lassila O., Ralph R.S. Resource Description Framework (RDF), Model and Syntax. W3C Recommendation. https://www.w3.org/TR/WD-rdf-syntax-971002/. 10 February 1997, Last accessed: 30 April 2017.

[31] OWL, Web Ontology Language Overview, W3C Recommendation, Deborah L. McGuinness, Frank van Harmelen, Stanford University, Online: https://www.w3.org/TR/owl-features/, 10 February 2004, Last accessed: 30 April 2017.

[32] OWL 2.0, OWL 2 Web Ontology Language Document Overview, W3C Recommendation, Online: http://www.w3.org/TR/owl2-overview/, 11 December 2012, Last accessed: 30 April 2017.

[33] Musen, M.A. Protégé ontology editor. Encyclopedia of Systems Biology, (2013), 1763-1765.

[34] Horrocks, I., Patel-Schneider, P. F., Boley, H., Tabet, S., Grosof, B., \& Dean, M. SWRL: A semantic web rule language combining OWL and RuleML.W3C Member submission, 21, 79. (2004), http://www.w3.org/Submission/SWRL/

[35] Sirin E., Parsia B., Grau B.C., Kalyanpur A., Katz Y. Pellet: A practical OWL-DL reasoner. Journal of Web Semantics. (2007); 5(2).

[36] Horridge M., Bechhofer S. The OWL API: A Java API for Working with OWL 2 Ontologies. In OWLED 2009, 6th OWL Experienced and Directions Workshop, Chantilly, Virginia, (2009).

[37] Java Script Object Notation (JSON). http://www.json.org/json-tr.html. Last accessed: 30 May 2017.

[38] Richardson L., Ruby S. RESTful Web Services. Web Services for the Real World. O'Reilly Media. ISBN: 978-0-596-52926-0. 2007; 454.

[39]Ertugrul, D. Ç., Elçi, A., \& Bitirim, Y. An Intelligent Tracking System: Application to Acute Respiratory Tract Infection (TrackARTI). In Computer Software and Applications Conference (COMPSAC'17), IEEE 41st Annual, (2017), Vol. 2, pp. 137-142. 